\title{
Book Reviews
}

topically oriented chapters. Langstaff, who trained in a Toronto proprietary school that could not offer a medical degree, followed by a year at Guy's Hospital where he studied with some of the medical luminaries of his age, brought new diagnostic and therapeutic medical science to the bedside. He adopted the flexible stethoscope, thermometer, and ophthalmoscope soon after their introduction in the medical literature, and took up new drug regimens while letting the heroic measures drop away over the years.

Duffin comments about how Langstaff's responses can be read in light of latetwentieth-century medical knowledge and often suggests present-day diagnostic nomenclature to illuminate the case histories. She admits that "a medically qualified person cannot read these documents without attempting to 'diagnose" 'Langstaff's patients (p. 71). She does this carefully, always noting whether or not her observation would have been available to Langstaff, and she suggests that "historians are not obliged to forget what they know now" (p. 92), but must try to understand illness categories within their own historical context.

Duffin's writing is evocative in small ways that readers appreciate. An example is when she describes Langstaff's speech before the city council on the bad condition of the roads, which he knew too well from personal experience, as a "cathartic opportunity" (p. 229). She relates that he fixed a patient's dislocated shoulder, "working outside, as he often did" (p. 157) providing us with a vivid glimpse into daily medical exertions. The book is rounded out with maps of the practice, family and community photographs, and numerous tables and appendices, all of which add to its fullness. This is an altogether satisfying book: it is scholarly, sound, exceedingly readable, and we come away having learned something.

Judith Walzer Leavitt, University of Wisconsin-Madison
Miriam Bailin, The sickroom in Victorian fiction: the art of being ill, Cambridge University Press, 1994, pp. ix, 169, £30.00, \$49.95 (0-521-44526-4).

"The sick role"-a happy coinage of the American sociologist Talcott Parsonsprovides an rich entrée into the social, cultural, moral and personal functions of the sick-bed. That the sickroom was far more than an exclusively medical space was clearly recognized by the Victorians: once social pathologies had been transformed into bodily ailments, it was the task of "life in the sick room" (the title of Harriet Martineau's book on that very subject) to develop social rituals of healing that would mend hearts and relations not less than limbs-as ever, Oscar Wilde had an epigram for it: "I died and came to life again as a patient". Not surprisingly a cult of sickness developed, notoriously amongst families like the Darwins, as illness was discovered to be a source of solace no less than of suffering. For, as Miriam Bailin points out in a perceptive introductory chapter, the sickroom (like the death-bed) became a privileged space where enmities could be ended, confidences shared, and physical intimacies enjoyed free of the snares of sexuality that so often troubled Victorians. In a cruel world, the sickroom secured a rare interlude of kindness.

The core of Dr Bailin's slim book, given over to case studies of the sickroom in major Victorian novels, unfortunately does not live up to the promise of her Introduction. A chapter on Charlotte Brontë hardly goes beyond paraphrase, while another devoted to George Eliot seems misplaced, since (apart from the problematic Romola) she was not a devoted "sickroom" writer, Dr Bailin fascinatingly demonstrates that many of Dickens' restless characters finally find rest in illness and experience an emancipatory and redemptive delirium. But given that Dickens provides so many powerful scenes of sickness and nursing-Eugene Wrayburn and Lizzie Hexam, Arthur Clenham and Little Dorrit, Dick Swiveller with the Marchioness, Oliver 


\section{Book Reviews}

Twist with Mr Brownlow and with the Maylies, and so forth-it is a pity that the chapter is rather slender. Overall this is a stimulating work, but, by contrast with such recent books as John Wiltshire's Jane Austen and the body: 'The picture of health' (Cambridge University Press, 1991), it provides less than it promises.

Roy Porter, Wellcome Institute

Lynn Bindman, Alison Brading, and Tilli Tansey (eds), Women physiologists: an anniversary celebration of their contributions to British physiology, London and Chapel Hill, Portland Press, 1993, pp. ix, 166, £9.99, \$15.00, (1-85578-049-6).

Physiology is a fascinating field for historians of gender and of women's place in science and medicine. In the United Kingdom at least, since the late nineteenth century, women's presence as undergraduate students in the field, as medical students and as subject specialists, has been relatively strong compared to their representation in science generally. A large body of public lectures and popular writing in "physiology" was produced by women for women from the 1860 s onwards. Much of this would now be labelled as health education or even sex education and dissociated from the academic discipline of physiology and its inseparable partner in Britain, the Physiological Society. Victorian women's exposure to academic physiology was controversial because of the subject's association with animal experimentation.

This modest volume is not directly about these broader issues although it does allude to them. Its main purpose is to celebrate the far from modest achievement of a small number of distinguished women physiologists. In the first section, E M Tansey provides a succinct overview of the history of women in the Physiological Society, noting that their admission, in 1915, was controversial, notwithstanding their publication record. Women's presence at the Society's dinners was clearly not welcome to all leading male physiologists of the time, yet they were accepted into the Physiological Society long before many other scientific societies. Section II gives brief biographies and edited extracts from published research for eight women whose contribution to science led to their becoming Dames of the British Empire or Fellows of the Royal Society. Section III provides biographical sketches of others whose distinguished scientific contribution did not attract such public honours.

The Afterword raises the questions any analytic historian would ask about any patterns in background, career paths, topic research etc. but has to admit that the small sample precludes satisfying answers. It also attempts comparisons with the current situation of women physiologists. Again, the focus on a few very distinguished women is not necessarily the best foundation for such comparisons. The book achieves its main aims of documenting the achievements of the few well, although, as often seems to be the case, these successful women scientists frustrate the historian by not generally indulging in extensive reflection on their own lives. One would hope that it will encourage others to extend the study of women's place in physiology in and outside academia to answer the broader questions it poses more satisfactorily.

Mary Ann Elston, Royal Holloway, University of London

Lawrence C Kolb and Leon Roizin, The first psychiatric institute: how research and education changed practice, Washington, DC, and London, American Psychiatric Press, 1993, pp. xx, 258, illus., $\$ 39.00$ (0-88048-544-2).

This book describes the history of the New York State Psychiatric Institute from 1896 to 1971. As historical writing it is badly flawed. No reference is made to any sources in the history of psychiatry after 1968 and the repetitive ascription of talent, foresight and 